\title{
How the Liverpool Tidal Institute was established: industry, navy and academia
}

\author{
Anna Carlsson-Hyslop \\ independent researcher, London, E17 3AL, United Kingdom \\ Correspondence: Anna Carlsson-Hyslop (annaecarlsson@gmail.com)
}

Received: 5 January 2020 - Revised: 30 May 2020 - Accepted: 13 June 2020 - Published: 22 July 2020

\begin{abstract}
This paper outlines the establishment of the Liverpool Tidal Institute in 1919. There is a particular focus on early patrons and supporters in the context of both previous tidal research on the accuracy of predictions and debates about the involvement of state actors in science at the end of the First World War. It discusses how, and to what extent, various actors - Liverpool University, the British Association for the Advancement of Science, the UK Hydrographic Office, and the shipping industry - became involved with the institute and what their roles were in its creation. It shows that industrial support was crucial in the establishment of this academic institute which later became a key contractor to the Navy.
\end{abstract}

\section{War, ship sizes, and tides}

As part of the centenary of the establishment of the Tidal Institute (TI), this article reflects on its foundation: how was it established? Who was prepared to support the early institute? How did that support manifest itself and how did it affect the research done?

I first set the scene by describing debates about the role of the state in science after the First World War and tidal work before TI. I then introduce key actors: Joseph Proudman, the Liverpool shipping industry, Liverpool University, the British Association for the Advancement of Science (BAAS), the Hydrographic Department (Hydro), Arthur Doodson and his team of computers, as well as their computing technology. After this I describe how these and other actors came together to create the unusual patronage structure of the institute through research and funding bids. I finally emphasise the continued role of tidal predictions in TI's finances for several decades to come.

\subsection{Science and the state}

Towards the end of the First World War, the state and military began to support and fund science much more extensively, but there is disagreement in the literature over the speed with which this took place. This may partly depend on the focus of the author: for example, whether the focus is pre-war and early war, or later during and after the war, and also on how you view the links between different organisations. The military had previously supported scientific research done within bodies such as the Hydrographic Office, which can be seen as directly part of the military, but during and after the First World War this closely connected network of state, military, and scientific organisations grew, with many more scientists and engineers brought into a wider complex of state support, funding, and influence.

Andrew Hull (1994) has argued that a significant number of new scientific bodies were established alongside TI through state and military involvement. In the UK, the Department of Scientific and Industrial Research (DSIR) - established during the war - was a key agent, establishing seven new research stations, including the Radio Research Board, between 1917 and 1920. The DSIR also created a number of co-operative industrial research associations and took over control of the National Physical Laboratory (NPL) from the Royal Society and the Geological Survey from the Board of Education (Rose and Rose, 1969, p. 45; Varcoe, 1974; Clarke, 2010). Hull sees the creation of these new organisations and the establishment of various military-scientific bodies such as the Board of Invention and Research at the Admiralty, the Munitions Invention Department for the Army, and the Air Inventions Committee as evidence for "a dramatic wartime conversion of the British government to be- 
lief in the worth of scientific research in war and peace, and a major financial commitment" (Hull, 1994, p. 79; Varcoe, 1974, pp. 44-46). Hull has challenged claims by authors such as Guy Hartcup, who stated that scientific and technological advances during the First World War consisted of "relatively simple pieces of engineering" and that military authorities not only neglected research and development in the pre-war era, but that they were also slow to realise the potential of science during the war (Hartcup, 1988, pp. 6 and 161).

As the first TI Secretary, Arthur Doodson (1890-1968), later noted, interest in tidal matters increased during the war, as the military recognised the potential of physical oceanography and hydrography (Weir, 2001; Deacon, 1984, p. 284) ${ }^{1}$. In 1919, Hydro organised an international conference that led to the creation of the International Hydrographic Bureau in 1921, intended to increase the exchange and standardisation of hydrographic information, including tidal data (Weir, 2001; Day, 1967, pp. 311-312). Another example of this is the establishment of the International Association of Physical Oceanography (IAPO, now called the International Association for the Physical Sciences of the Oceans, IAPSO) in 1919 as a sub-section of the new International Research Council (Smythe-Wright et al., 2019).

The increasing naval interest in oceanography may have provided a supportive environment for an organisation such as TI, but does not in itself explain the institute's materialisation. I will analyse the establishment of TI as a specific case study of the debates about the role of state patronage of science at the end of the First World War. I argue that rather than asking whether the war led to increased state and military funding of science in general, it may be more constructive to determine whether the war influenced what kinds of scientific work were conducted.

I will also discuss the arguments that secured patronage for TI: in other words, what secured TI not only funding but also other forms of necessary support. The institute's founders were able to argue the accuracy of tidal predictions required significant improvement by emphasising experiences during the war and a recent increase in the size of ships, appealing to the needs of both state and industry. However, while state actors had a long history of involvement in tidal science and did influence TI's research programme, they were not directly involved in the institute's creation and provided little funding. Financial patronage of TI originated from industry, an issue that has been somewhat neglected in the historiography of physical oceanography.

\subsection{Tidal work before $\mathrm{TI}$}

Michael Reidy described Hydro as "the research and development wing of the British Admiralty". It had taken a deep interest in tidal science since at least the early nineteenth cen-

\footnotetext{
${ }^{1}$ Arthur Doodson, Personal Information File, RSA (Royal Society Archive).
}

tury. Emphasising the close links between tidal research, the demands of merchant shipping, and military demands from the Admiralty at that time, Reidy argued that tidal research enabled the British commercial and military empire to control the seas (Reidy, 2008, p. 140; Hughes, 2005). From 1833 onwards, the Admiralty published tide tables, although the calculations were carried out by external contractors (Reidy, 2008, p. 116; Day, 1967, p. 47). The Admiralty continued to publish tide tables and engage with tidal science into the twentieth century (Day, 1967).

The tables Hydro and others published were calculated using various methods. The synthetic method, devised by John William Lubbock (1803-1865) (e.g. Lubbock, 1835) and developed with support from BAAS in the 1820s and 1830 s, was still in use in the twentieth century despite recognised limitations for areas with particular types of tides - it works better in areas with semidiurnal (twice daily) tides than those with diurnal (once daily) tides (Reidy, 2008; Hughes, 2005; Woodworth, 2020). During the 1860s, William Thomson (Lord Kelvin, 1824-1907), working as part of a BAAS committee, and the American William Ferrel (1817-1891), independently developed the harmonic method of tidal analysis and prediction. This worked on both semidiurnal and diurnal tides and required fewer data from tidal gauges. This was further developed by George Howard Darwin (1845-1912) in the 1880s, again with BAAS support (Hughes, 2005; Cartwright, 1999; Woodworth, 2020). BAAS support of tidal research appears to have been important though intermittent.

In 1912, Hydro appointed a full-time tidal officer, Commander Harold Dreyer Warburg (1878-1947). Entering the Navy in 1894, Warburg had conducted onboard surveys from 1899 to 1910 , when, due to deteriorating eyesight, he was restricted to desk duties. He swiftly began to focus on tidal research (Parry, 1918; Day, 1967, pp. 325-326). Following his work on prediction methods, computation of some non-harmonic tide tables was taken in-house by Hydro, and Warburg was appointed Superintendent of Tidal Work in 1917 (Day, 1967, pp. 325-326). Harmonic predictions continued to be made using tide-predicting machines (Woodworth, 2020) owned by Hydro's contractors. At the end of the First World War, Messrs. Roberts \& Son was one of the two external contractors used by Hydro, the other being the NPL (Day, 1967, p. 257).

Hydro's interest in tides and tidal research increased as the First World War put an end to the exchange of tidal predictions between countries, including Germany and the UK. Warburg initially experimented with what he described as the "scientific" harmonic method but, having noted substantial differences between predicted and observed tides for the now crucial North Sea ports, declared it "unsatisfactory". While tide predictor machines would only ever be able to provide an approximation of the tides, Warburg found differences of over an hour between harmonic predictions produced using such machines and those published in German 
tide tables for Heligoland. Instead he invented a "rough unscientific method" to predict these tides, and he claimed his equation method "gave good results" (Parry, 1918, p. 286). His equation method used lunitidal intervals and heights of high and low water, like Lubbock's method, but then calculated corrections for phase inequality and changes in the parallax and declination of the moon and sun. The demands of war had led Warburg to identify problems with the harmonic method, arguing that it did not produce "good enough" predictions, in opposition to what Darwin (1884) had argued at the end of the nineteenth century. Warburg argued that further work in this area was necessary, implicitly calling for additional funding (Parry, 1918).

Warburg gave a detailed technical presentation of his new methods to the Royal Geographical Society in February of 1919 (Parry et al., 1919). He emphasised that while the number of tidal predictions published by the Admiralty had increased to 56 since they were first published in 1833 , "there had been no corresponding increase in accuracy" despite "the increase in size, speed and draft of vessels" long before the war (Warburg, 1919, pp. 308-309). During discussion of Warburg's paper, the Hydrographer of the Navy, Rear Admiral Sir John Parry, stated that the laying of mines, avoidance of torpedoes, and rapid movement of ships during the recent war had all relied on tidal predictions: "if a vessel is being chased, it may be a question of life or death to her to be able to decide whether she may cross over a shoal or not, and the disadvantage of not being able to cross and having to go round the shoal is obvious to us all" (Parry et al., 1919, p. 327).

\subsection{Joseph Proudman (1888-1975)}

Joseph Proudman, who would go on to become TI's Director, had grown up on a farm in Bold, between Widnes and St Helens, Merseyside, before winning a scholarship to study mathematics at the University of Liverpool, gaining a B.Sc. in 1909 and B.Sc. Honours in 1910 (Cartwright and Ursell, 1976). Securing a second scholarship, he then studied pure and applied mathematics at Trinity College, Cambridge. Passing the Mathematical Tripos in 1912, with distinction and first class grades in the final examination, he spent a third year at Cambridge carrying out research: it was here that he became interested in tides (Warwick, 2003, pp. 284285). Proudman's earlier interest had been electricity, but being unable to find the "definite problem" he desired, despite talking to a number of mathematicians in Cambridge, including Joseph Larmor, his Director of Studies eventually recommended that Proudman write to Horace Lamb (18491934), Professor of Mathematics at the Victoria University of Manchester. Lamb, who had worked on the mathematical theory of tides and other oceanic waves, including tsunamis, replied "[b]y return of post" with a problem in this area that
Proudman deemed worthy of his efforts (Love and Glazebrook, 1935) $)^{2}$.

Proudman had taken a post as lecturer in mathematics at Liverpool University in 1913 and became a Fellow of Trinity College in 1915. Having been placed in a "low medical category", he remained in Liverpool conducting tidal work during most of the First World War. However, he worked on ballistics in Woolwich Arsenal's Research Department for the last half of 1918, producing a paper on "the gyroscopic dirft [sic] of a shell" 3 . There he also worked with the Professor of Naval Architecture, Thomas Bertrand Abell (1880-1956), thus establishing some personal networks with the military world ${ }^{4}$.

Proudman practised a type of mathematical physics originating from Cambridge University (Warwick, 2003), stemming from Laplace's work on the hydrodynamic theory of long waves. Proudman was TI's main practitioner of this type of hydrodynamical work and the institute's link to the Laplacian tradition, having learnt this technique and the skills required to practise it during his time at Liverpool University (Warwick, 1992, pp. 639 and 644). He describes his undergraduate studies at Liverpool as "work[ing] out vast quantities of examples" set, corrected, and criticised by his lecturers, all of whom had studied mathematics at Cambridge; he was developing some of the specific problem solving and learning skills used by Cambridge mathematicians, much like the public school students discussed by Andrew Warwick $(2003)^{5}$.

\subsection{The shipping industry and the university}

Liverpool University and the city's shipping industry were heavily involved in the early days of TI. However, although the university formally established TI, it provided very little financial support. As was then common for English provincial universities located in industrial towns, the university had relied on local industry since its predecessor Liverpool University College was established in 1881 with GBP 6230 donated by ship owners towards a chair of mathematics (Kelly, 1981, pp. 48-49). These "red brick" universities were therefore rather different in their funding structure and nature compared to Oxford and Cambridge. Although the significance of industrial donations decreased as funding was secured from other sources, the shipping industry continued

\footnotetext{
${ }^{2}$ Joseph Proudman Biographical lecture D 212/2, LUA (Liverpool University Archive, Liverpool University Sydney Jones Library).

${ }^{3}$ Joseph Proudman, Personal Records of Fellows of the Royal Society, 8.2, RSA.

${ }^{4}$ University Council Report book, 1918, S2466, LUA.

5 Joseph Proudman Biographical lecture D 212/2, LUA. According to Proudman, Professor Frank Stanton Carey had been third wrangler around 1880, and another lecturer, James Mercer, was senior wrangler in 1905. A wrangler was an Cambridge University graduate who had obtained first-class honours in mathematics.
} 
to contribute noticeable sums to developments such as the School of Tropical Medicine in 1899 and the Chair in Naval Architecture in 1909 (Kelly, 1981). Research carried out for the shipping industry at the university included the use of cement in waterworks construction, cold storage machinery, and marine propulsion using the internal combustion engine (Jones, 1989, pp. 73-74). Donations from the shipping industry continued during and after the First World War, resulting in four chairs in engineering being established in 1920 (Kelly, 1981, p. 245).

In 1919, the Department of Oceanography was created, endowed by Natural History Professor William Abbott Herdman and his wife. Biological oceanography had existed at the university since the 1880 s, with a marine biology station established in 1887 and moved to Port Erin on the Isle of Man in 1892, when the Fisheries Laboratory also became part of the Natural History Department (Kelly, 1981, pp. 7273). Herdman had successfully argued that this research was important for the fishing industry and received financial support from both local industry and the government for this "applied biology" (Jones, 1989, pp. 94-100). The Department of Oceanography initially concentrated on biological oceanography, and so was not in direct competition with TI's mathematically based physical oceanography.

Instead of receiving funding from the university, TI received support from industry. When established in 1919, the shipping line owners and brothers Alfred (1872-1948) and Charles Booth (1868-1938) provided GBP 350 per year towards the TI Secretary's salary and GBP 50 per year towards working expenses for 5 years ${ }^{6}$. The Booths were part of a modernising faction within the Liverpool shipping community who owned and managed ocean liners of increasing size, had links with university science as well as the state, and, spurred on by the First World War, were keen to increase the port's throughput.

Alfred Booth had studied mathematics at King's College, Cambridge, graduating in 1894. While not excelling, he would have been capable of understanding enough of Proudman's work to appreciate the type of research TI was intending to carry out ${ }^{7}$. Having been Chairman of the Board of Trade Committee on the Shipping and Shipbuilding Industries and a member of Lord Balfour's Committee on Commercial and Industrial Policy in 1916, Alfred was involved in national politics. Charles Booth was similarly involved in a range of organisations and companies and, crucially, was on the Liverpool University Council for many years, forming a link between the shipping world and the university. He was also involved in port organisations, as Chairman of the Employers' Association of the Port of Liverpool (1919-1938)

\footnotetext{
${ }^{6}$ Gift book 1 October 1903-September 1912, February 1919, S81, LUA.

${ }^{7}$ Cambridge University Reporter, 29 May 1894, p. 846, and 12 June 1894, p. 904.
}

and later as a member of the Mersey Docks and Harbour Board (1924-1938) (John, 1959).

Another of TI's industrial patrons, represented on the governing committee from 1920, was the Mersey Docks and Harbour Board (MDHB). This was a large organisation heavily dominated by shipping companies that had run Liverpool's port since 1858 (Mountfield, 1965). As the height of tides determined when larger ships could access the port (Shoolbred, 1906), MDHB had a longstanding interest in tidal prediction, as evidenced by the existence of committee papers detailing several investigations into tide tables produced by different organisations ${ }^{8}$. As Table 1 illustrates, tonnage per vessel had increased from $375 \mathrm{t}$ per vessel in 1880 to $771 \mathrm{t}$ in 1914 and $996 \mathrm{t}$ in 1919. Companies running passenger and cargo ocean liners were demanding new docks for ships with 34 foot $(10.4 \mathrm{~m})$ draughts. In response, the Docks Board organised new dock facilities and "improvements" to the Mersey, including training walls to control river channels (Mountfield, 1965, p. 140).

The introduction of ocean liners and the large increase in ships using Liverpool docks during the First World War increased costs and created both congestion and labour shortages. The Liverpool Committee for the Co-ordination of the Naval, Civil and Military Requirements of the Port had been established in 1915 by the central government to reduce congestion. Chaired by Alfred Booth and representing a range of interests, including MDHB shipowners, the Navy, labour organisations, and railway owners, the committee had initially been criticised by the more traditionalist MDHB (Mountfield, 1965, pp. 126-134) ${ }^{9}$. However, according to the economic historian Francis Hyde (1971), "measures were taken as a result of the war to improve efficiency [i.e. increase the port's throughput]", and MDHB resistance dissipated.

\subsection{The BAAS connection}

During the First World War, a BAAS committee of senior scientists under Section A (Mathematics and Physics) set up a survey of geodetic research, in part to maintain scientific interest in geophysics following the death of the astronomer George Howard Darwin, who had studied the relationship between tides and their "kindred phenomena in the solar system" (Dyson, 1917). The committee argued that a geodetic institute, covering geodesy, seismology, terrestrial magnetism, and tides, would provide the government with information that no other research institution could. This was part of a wider agenda to increase links between science, military, and government, identified at BAAS and elsewhere in relation to the establishment of the DSIR (MacLeod, 1970;

\footnotetext{
${ }^{8}$ MDHB WUP T111 “Liverpool Tide Tables”, MMM (Merseyside Maritime Museum Archive).

${ }^{9}$ Tidal predictions do not appear to have been considered by the committee. D42/C1/1/18, Liverpool Committee for the Coordination of the Naval, Military and Civil Requirements of the Port, LUA.
} 
Table 1. The total number of vessels and the total tonnage for which MDHB was paid rates, the ratio of which shows the increase in tonnage per vessel between 1880 and 1920 (from Mountfield, 1965, Appendix IV).

\begin{tabular}{|c|c|c|c|}
\hline Year & $\begin{array}{r}\text { Total number } \\
\text { of vessels }\end{array}$ & $\begin{array}{l}\text { Total tonnes net } \\
\text { registered tonnage }\end{array}$ & $\begin{array}{r}\text { Tonnage } \\
\text { per vessel }\end{array}$ \\
\hline 1880 & 20070 & 7524533 & 375 \\
\hline 1881 & 20249 & 7893948 & 390 \\
\hline 1882 & 20966 & 8104136 & 387 \\
\hline 1883 & 21315 & 8527531 & 400 \\
\hline 1884 & 23940 & 8800362 & 368 \\
\hline 1885 & 21529 & 8571454 & 398 \\
\hline 1886 & 20598 & 8370723 & 406 \\
\hline 1887 & 21884 & 8797783 & 402 \\
\hline 1888 & 22241 & 9017935 & 405 \\
\hline 1889 & 22662 & 9291964 & 410 \\
\hline 1890 & 23633 & 9654006 & 408 \\
\hline 1891 & 22775 & 9772506 & 429 \\
\hline 1892 & 22304 & 9968697 & 447 \\
\hline 1893 & 21206 & 9468539 & 447 \\
\hline 1894 & 21170 & 9960902 & 471 \\
\hline 1895 & 23943 & 10777146 & 450 \\
\hline 1896 & 23695 & 11046459 & 466 \\
\hline 1897 & 23640 & 11473421 & 485 \\
\hline 1898 & 24664 & 11815376 & 479 \\
\hline 1899 & 25522 & 12534116 & 491 \\
\hline 1900 & 24870 & 12380917 & 498 \\
\hline 1901 & 24334 & 12648539 & 520 \\
\hline 1902 & 24214 & 13308305 & 550 \\
\hline 1903 & 24827 & 14537751 & 586 \\
\hline 1904 & 25400 & 15626241 & 615 \\
\hline 1905 & 26065 & 15996387 & 614 \\
\hline 1906 & 25773 & 16147856 & 627 \\
\hline 1907 & 25635 & 17064211 & 666 \\
\hline 1908 & 25739 & 17111814 & 665 \\
\hline 1909 & 24799 & 16747479 & 675 \\
\hline 1910 & 24961 & 16654071 & 667 \\
\hline 1911 & 25377 & 17600888 & 694 \\
\hline 1912 & 23483 & 17327415 & 738 \\
\hline 1913 & 24982 & 18433269 & 738 \\
\hline 1914 & 24756 & 19086672 & 771 \\
\hline 1915 & 22562 & 18980913 & 841 \\
\hline 1916 & 18742 & 15679943 & 837 \\
\hline 1917 & 16747 & 14018652 & 837 \\
\hline 1918 & 11855 & 11687204 & 986 \\
\hline 1919 & 12372 & 12324010 & 996 \\
\hline 1920 & 17115 & 16521373 & 965 \\
\hline
\end{tabular}

MacLeod and Andrews, 1971; Hull, 1999) plus an emphasis within BAAS on utilising science for "national efficiency" (MacLeod, 1981, p. 2).

In 1916, as part of the wider BAAS survey, Horace Lamb asked his protégé, Proudman, to help with a report on the current state of tidal research (Proudman, 1968, p. 193). Contradicting the main geodetic committee's claims that the proposed institute would assist the state, Lamb and Proudman (1919, p. 15) maintained that existing tide tables were "sufficiently accurate" for practical needs; it was research on the dynamic theory of tides that required "improved" predictions of periodic tides to address such issues as uncertainties in harmonic constants for long-period periodic tides due to "meteorological disturbances".

The Hydrographer of the Navy, Rear Admiral Sir John Parry, noted this disconnect between academic tidal research and the work of "practical men". In 1918, Parry chaired a geophysical discussion at the Royal Astronomical Society organised by BAAS as part of their campaign for increased state support of geodetic research, at which Warburg, Lamb, and Proudman all made presentations (Dyson, 1917). The Hydrographer stated that he had only accepted the chair in order to emphasise the need for cooperation between "practical" men, like himself and Warburg, and "scientific" men, such as Lamb and Proudman (Parry, 1918). Despite this call for increased tidal research from the Hydrographer, Hydro offered no financial assistance either to the proposed Geodetic Institute or the Tidal Institute.

The proposed state-supported Geodetic Institute never materialised, but other actors, including the Royal Society, were working towards setting up a similar but privately funded body at Cambridge University. Hull (1999) has argued that at that time BAAS was more radical than the Royal Society in its demands for increased state funding of science, and the fate of the Geodetic Institute may be an example of these institutional politics.

\subsection{The establishment of TI}

In early 1918, Proudman still had hopes of heading the tidal department of the proposed Geodetic Institute, but as this became less likely, he began to formulate plans for a separate industry-funded tidal institute at Liverpool. By November he had formulated a memorandum to be put to the local shipping men via the Professor of Mathematics, F. S. Carey (1860$1928)^{10}$. In early 1919 Proudman met with Charles Booth, then on the university's council, who described the proposed Tidal Institute as a "capital idea", and within a few days he and his brother Alfred had promised GBP 400 per year for

\footnotetext{
${ }^{10}$ Doodson to Margaret, 19 February 1918, 17 June 1918, and 19 November 1918, Doodson Papers (Liverpool World Museum, National Museums and Galleries on Merseyside).
} 
5 years ${ }^{11}$. The university then became involved, establishing TI "as proposed in the letters" from the Booth brothers ${ }^{12}$.

With Proudman as director - the role was unpaid, but he remained employed by the university and promoted to Professor of Applied Mathematics - and Arthur Doodson as secretary, the new institute was housed by the university in a room at the Holt Physics Laboratory. As space at the university was in great demand, this demonstrated a willingness to encourage $\mathrm{TI}^{13}$, but only a minimal grant was provided, initially GBP 10 per year ${ }^{14}$. The original governing committee had six members from the university and the Booths, but by 1920 it had expanded to 15 , and while there was still a strong contingent of shipping men, scientific representatives now dominated.

Another of TI's early sources of funding was BAAS, which as discussed earlier had provided intermittent support of tidal research since the 1830s and now picked up the topic again. In the wake of the proposed Geodetic Institute, Section A (Mathematics and Physics) had set up a tidal committee chaired by Doodson. In the autumn of 1919, TI's first year, this committee was given GBP 150, the largest grant within Section A, which was allocated to TI to pay computational staff. BAAS funding of the committee quickly declined, however, and ceased completely in 1922.

\section{Tl's research programme}

Proudman had proved himself proficient at securing opportunities and funding for himself and his chosen field, but this required a great deal of effort. He looked for funding wherever he could, gradually adjusting his portrayal of TI's research programme to fit his audience, inventing his institution-building strategies along the way as he identified potential avenues for research.

\footnotetext{
${ }^{11}$ Doodson to Margaret, 4 February 1919, Doodson Papers, and Joseph Proudman, Personal Records of Fellows of the Royal Society, RSA, 9.1. A few letters from Arthur Doodson to his future wife mention discussions with Proudman on the proposed TI, but they do not cover why it was proposed (Doodson to Margaret, 19 February 1918, 17 June 1918, and 19 November 1918, Doodson papers). No letters to or from Proudman or the Booths on this issue appear to have been preserved. The establishment of TI is recorded in the University Council Minutes, but this gives little information (University Council Minute 18 February 1919, S2221, LUA). The University Gifts book provides confirmation of the Booth's monetary gifts, with Alfred Booth giving GBP 350 towards payment of the salary for the TI Secretary, while Charles Booth gave GBP 50 towards working expenses, both annually for 5 years (Gift book 1 October 1903-September 1912, February 1919, S81, LUA). These official university notes are the only direct primary sources on TI's establishment. Other actors' minutes (e.g. MDHB main Board and its Marine Committee) do not even record the establishment of TI.

${ }^{12}$ University Council Minute 18 February 1919, S2221, LUA.

${ }^{13}$ Doodson to Margaret, 12 February 1919, Doodson papers.

${ }^{14}$ Tidal Institute Ledger, S2147, LUA.
}

Proudman would later describe his belief that "there was an opportunity for an institute" researching tides in Britain as a response to the gaps in academic work highlighted by the BAAS study and his own 6 years of theoretical research (Proudman, 1968, p. 193). He had gradually realised that such an institute was potentially fundable by the shipping industry if related to actual tides ${ }^{15}$. In 1919, Proudman wrote to Geoffrey Ingram Taylor (1886-1975), a Cambridge mathematician and physicist he had worked with on the theory of disturbances to a rotating fluid caused by a moving solid ${ }^{16}$, stating that TI was set up in order to advance the work suggested in the BAAS report through "one man spending the whole of his time on material relating to actual tides" 17 . Proudman was still emphasising the more theoretical work suggested by the BAAS report, but this was now to be carried out on actual, as opposed to theoretical, tides. While the issue of tidal prediction had never been at the forefront of his ambitions, discussions with the Booths had revealed the significant industrial demand for work on this (Proudman, $1920)^{18}$.

\subsection{The role of the Navy}

For Proudman, establishing TI was important both for championing his chosen topic of research and establishing his own career. For Liverpool University, TI was another research institute funded by local shipping men, while for the industrial funders TI was part of a wider modernising agenda, intended to increase the port's throughput and allow safe passage for the increasingly large ships they owned and managed. While TI was a part of the creation of new scientific organisations described by Hull (1994), at this early stage it was not directly linked to state actors through funding, especially not after the collapse of plans for the Geodetic Institute. However, the Hydrographic Department of the Admiralty swiftly became involved in defining TI's research programme.

Proudman and Doodson started exchanging information and requesting advice from Hydro in the late summer of 1919 - the earliest preserved letters are dated August 1919 - over half a year after TI had been established. Demonstrating the initially distant relationship between the two organisations, these formal, impersonal letters also reveal Hydro's increasing involvement with TI's work. Hydro believed tidal predictions were particularly poor for shallow water ports, an issue identified by Warburg's work during the war ${ }^{19}$. Although TI

\footnotetext{
${ }^{15}$ Doodson to Margaret, 19 November 1918, Doodson Papers.

${ }^{16}$ This collaboration led to the formulation of what is now called the Taylor or Taylor-Proudman column (Cartwright and Ursell, 1976, p. 324).

${ }^{17}$ My emphasis. Proudman to Taylor, 18 March 1919, GIT D66, Trinity College Library, Cambridge.

${ }^{18}$ Proudman to DSIR, 8 July 1919, DSIR 36.13.4, NA (The National Archives, Kew, London).

${ }^{19}$ Correspondence in folder "Machine tests", Box 126, Bidston Archive, Liverpool World Museum, National Museums and Gal-
} 
responded to these suggestions, in 1920 Warburg related to the Hydrographer that he had informed Proudman that TI's choice of port for in-depth analysis, Newlyn (Penzance), had too few shallow water effects to provide a good basis for new calculating methods ${ }^{20}$. Nevertheless, Hydro's attempts to influence TI's tidal research to fit its own agenda, without actually paying for the work, had some impact on TI's work.

Around the time of TI's establishment, discussions were taking place within Hydro regarding the quality of the tidal predictions they had purchased. In 1920, when the India Office moved its tidal predictor machine from NPL in Teddington to India, Messrs. Roberts \& Son became their only external provider of predictions. Several members of staff debated investing in their own machine and taking at least some of the calculations in-house, thereby preventing a monopoly and reducing the government's dependence on private business, which could increase charges or reduce services at will ${ }^{21}$. Both Hydrographer Learmonth and the Director of Scientific Research, Frank Edward Smith, initially recommended the purchase. However, Warburg's report after a visit to Messrs. Roberts \& Son sufficiently allayed concerns about the quality of predictions and the possibility of disruption. The poor state of Hydro's finances was also a factor ${ }^{22}$. Although Hydro was clearly concerned about the quality of tidal predictions at this time, the possibility of becoming involved with or funding TI was not even raised in these debates.

While my findings may appear to support those who have argued the Navy was slow to acknowledge the possibilities of academic science, this is not my interpretation. Rather, as demonstrated at the 1918 Royal Astronomical Society geophysical meeting on tides, they sought to encourage "scientists" to work with "practical" men, such as themselves, to improve tidal predictions. The Navy was keen to communicate and cooperate, but does not at this stage appear to have considered that financial support of TI from the Navy's limited resources was the way forward ${ }^{23}$. There was no obvious, established practice for state and science to work together at this time; the form that such cooperation could take was therefore up for discussion.

If anyone, it was Proudman who underestimated naval needs for tidal research. He later claimed not to have realised how bad predictions were viewed by seafarers until after TI was established, despite the comments made during the geophysical meetings (Proudman, 1920) ${ }^{24}$. However, it is clear that complaints and suggestions by Hydro and other inter-

leries on Merseyside. Doodson acknowledges this in his work (Doodson, 1920).

${ }^{20}$ Minute, 3 July 1920, H 4567/20, UKHO (United Kingdom Hydrographic Office Archive, Taunton).

21 "Proposal to establish an Admiralty tide predicting machine," Memorandum by Hydrographer Learmonth, 25 May 1921, H4434/23, UKHO.

${ }^{22}$ Documents in file HYD 587/1921, within H4434/23, UKHO.

${ }^{23}$ Documents in file HYD 587/1921, within H4434/23, UKHO

${ }^{24}$ Proudman to DSIR, 8 July 1919, DSIR 36.13.4, NA. ested parties, such as the Booth brothers, steered TI's early research programme towards an emphasis on tidal predictions. The institute's intended research, as presented to potential or actual patrons, had shifted from the theoretically oriented agenda developed for the unsuccessful BAAS geodetic institute to a practical research programme funded by shipping men and influenced by Hydro. In TI's first annual report by Proudman and Doodson (Liverpool Tidal Institute, 1920), the general improvement of tidal predictions was presented as a key justification for TI's existence and funding. This report also detailed the issues with existing tidal predictions. As Warburg had stated, predictions for a port such as Liverpool varied substantially between different suppliers. Also, when comparing predicted and observed tidal heights using records from tidal gauges, there were large differences that TI's researchers termed residuals, e.g. meteorological effects. The reduction of these residuals was believed to be a major step towards increasing the "accuracy" of tidal predictions (Liverpool Tidal Institute, 1920).

Naturally, the institute had wider goals: to conduct scientific research on tides, train students in applied mathematics, be a "bureau of organised information concerning the tides", and carry out commercial research (Liverpool Tidal Institute, 1920, p. 5). It is clear, however, that the way Proudman framed demand for the work shifted with his audience. Having secured patronage from shipping men and alliances with Hydro, he now emphasised the importance of improving tidal predictions for shipping, the necessity of which he had denied in the report to BAAS.

\subsection{Arthur Doodson and practices of calculation}

In 1913, Arthur Doodson had been one of Joseph Proudman's first research students, and when offering him the post of TI Secretary, Proudman linked Doodson's skills to the institute's future patronage:

When the number of years [of funding from the Booths] is up (and possibly before) the work done will be reviewed and if it is considered to warrant it, an attempt will be made to fund a permanent institute on a larger basis, by appealing to the remaining ship owners of Liverpool. From what I know of the subject and your ability I am certain that if you come now the thing will be a success. ${ }^{25}$

Andrew Warwick (1997, p. 313) has argued that new technologies of calculation during the nineteenth century enabled the application of mathematical analysis to the needs of business and the military, as well as scientific work. The practices of calculation Doodson learnt during his early career were a key part of Proudman's and Doodson's institution building for TI. To justify their work and funding, they

\footnotetext{
${ }^{25}$ Proudman to Doodson, quoted in Doodson to Galloway, 6 February 1919, Doodson papers.
} 
had to convince others that earlier methods were not "accurate enough". As Graeme Gooday $(2004$, p. 268) has made clear, the definition used by scientists and others of accurate enough often changes over time: "What counted as accuracy was what constituted a sufficient degree of accuracy for a particular purpose to be undertaken within existing contextual constraints of money and time to the satisfactions of relevant audiences". Existing calculation technology will have been part of the contextual constraints. This applied not only to precision measurement, but also to precision calculation. Such arguments were also not only about science but also about patronage from state, industrial, and other actors.

Along with statistics, applied mathematics, and manual calculations, Doodson's particular skills were in precision engineering and the use of mechanical calculators ${ }^{26}$. In his research work, he had organised mathematical problems in a way that was amenable to manual calculations and then managed these calculations, skills he would later use at TI. Like Proudman, Doodson was not from a privileged background. His father was a cotton mill manager for a time but had problems with employment; attendant financial difficulties meant Doodson could not attend secondary school full time. Again like Proudman, he took a pupil-teacher role while attending half-days and evening classes at various schools in Leigh and Rochdale, just outside Manchester ${ }^{27}$. Doodson initially studied sciences at Liverpool University in 1908 while also training as a teacher, but abandoned the latter when he became profoundly deaf. He gained a first class B.Sc. degree in 1911 in chemistry and mathematics and then a first class honours degree in mathematics in 1912 (Proudman, 1968).

Doodson's disability made finding employment difficult, but he secured a post as a meter tester at Ferranti in Hollinwood from late $1912^{28}$. The debts he had accumulated while attending university meant a continual search for better paid opportunities ${ }^{29}$, and when the managers at Ferranti were asked to recommend a person for a post at Manchester Corporation in 1914, they nominated Doodson ${ }^{30}$. He began working at the Testing and Standardising Department as a "polyphase meter and instrument tester" and stayed there throughout the early war years ${ }^{31}$.

In 1913, Doodson had registered as a part time research student at the University of Liverpool's Department of Mathematics and was awarded a M.Sc. degree in 1914. Under Proudman's supervision his talent for organising computa-

\footnotetext{
${ }^{26}$ Doodson used his skills in light engineering and precision measurements to redesign tidal-predicting machines (Doodson, 1926).

${ }^{27}$ Doodson Personal Information File, section 6, RSA.

${ }^{28}$ Doodson to Galloway, 9 December 1912 and "probably October 1913", Doodson papers.

${ }^{29}$ Doodson to Galloway, 1 April, 1, 11, and 18 March 1914, 14 June 1914, Doodson papers.

${ }^{30}$ Doodson to Galloway, 14, 20 July 1914, Doodson papers.

${ }^{31}$ Doodson to Galloway, 1 August and 14 October 1914, Doodson papers.
}

tions was developed by working on Riccati-Bessel functions and tables of sines and cosines of radians (Proudman, 1968). Doodson sent the latter to the BAAS committee on mathematical tables, which published them and awarded him a place on the committee during 1915 and $1916^{32}$. Following his Masters' work Doodson continued his collaboration with Proudman, producing tables and graphs related to the diffraction or scattering "of a plane electromagnetic wave by a perfectly conducting sphere" (Proudman et al., 1918) ${ }^{33}$.

A conscientious objector for religious reasons, Doodson wrote to a friend in August 1915 that "nothing will drive me into the army or even into association with it in any shape or form" 34 . Brought in front of the local conscription tribunal in March 1916, he was eventually given "absolute exemption" on conscientious grounds with the condition he carry out work of "national importance" 35 . Doodson began work at Draper's Biometric Laboratory, run by Karl Pearson (18571936) at University College London in late September that year ${ }^{36}$.

Initially enjoying the work, Doodson provided the results of a particular calculation to eight figure accuracy - two more than usual - using an interpolation method he developed when working on diffraction with Proudman ${ }^{37}$. However, in 1917 Pearson's laboratory was turned over to war work, producing calculations for the Anti-Aircraft Experimental Section (AAES) of the Munitions Inventions Department. The war-related work made Doodson feel his "hands were not clean but bloodstained" and he seriously considered leaving ${ }^{38}$. Also during 1917, changes were made in the calculation practices used in the laboratory. Many of these were instigated by Doodson following disputes with Pearson, and Doodson was gradually and informally promoted.

\footnotetext{
${ }^{32}$ Doodson to Galloway, 14 May 1914, Doodson papers.

${ }^{33}$ Doodson to Galloway, 20 July, 1 August, 17 December 1914, 14 March 1915, Doodson papers.

${ }^{34}$ Doodson to Nightingale, 4 August 1915, Doodson papers.

${ }^{35}$ Doodson to Galloway, 13 April; 4 March 1916, added notes dated 1954; 23 March 1916, Doodson papers. In a 1954 note he explains that the tribunal refused to deal with him as a conscientious objector because of the subsidiary grounds and that he was treated roughly and called names. He writes that his case was mentioned twice in Parliament. For example, he was called "a disgusting mass of shivering fat" by one member of the Shaw tribunal, and this was referred to in Parliament as an example of poor treatment of conscientious objectors in the tribunals; see Hansard, "Army Estimates, 1916-1917”, HC Deb 16 March 1916, Vol. 80, c2435, https://api.parliament.uk/historic-hansard/commons/1916/mar/15/ conscientious-objectors\#S5CV0080P0_19160315_HOC_115, last access: 5 January 2020.

${ }^{36}$ Doodson to Galloway, 9 December 1915, Doodson papers.

${ }^{37}$ Doodson to Galloway, summer and autumn 1916, especially 14 November 1916, Doodson papers.

${ }^{38}$ Doodson to Galloway, 24 January 1917, Doodson papers; Doodson to Galloway, December 1916 and January 1917, Doodson papers.
} 
The development and usage of Doodson's methods and practices continued in early 1918, when the Director of Ordnance at Woolwich visited University College London to find out about one of the methods Doodson had developed: the small arc method ${ }^{39}$. However, Doodson was feeling less and less happy with Pearson, was concerned about his future prospects, and still felt the war work stained him: "This kind of work can never receive the blessing of God; of that I am certain" 40 . In late March, Doodson took over the management of AAES work as Pearson stepped down. Although this meant he was working directly for the Munitions Inventions Department ${ }^{41}$, he decided to accept the post "as its principal service was in connection with the protection of London against Zeppelins" 42 . As Director of the Computing Branch, Doodson was now "responsible for all computations and tables respecting anti-aircraft gunnery and a staff of about 15 computators" 43 , and he continued work at AAES beyond the Armistice.

\subsection{Tl's computers, calculating machines, and working practices}

Before starting at TI, Doodson had no experience of tidal work (Cartwright, 1980), but he had acquired a range of skills required for precision measurement and calculation and in organising complex calculations. At TI, Doodson had assistants known as computers. Although the first computer was Miss A. L. Cooper, who had worked for Doodson in London during the war and had a B.Sc., these roles were usually filled by female school leavers ${ }^{44}$. The number of computers rose in line with the number of tidal predictions carried out by TI, reaching 13 women by 1959 (LOTI, 1959).

The computer role included a mix of scientific work, general administrative duties, and housekeeping. Joyce Scoffield (2006) has described her duties as a junior computer in the early 1960s. Along with observing the weather and operating the tidal prediction machines, she was required to "fire the one-o'clock gun, to do 'differencing' and to make coffee for everyone and prepare lunch for the male staff'. The differencing methods Scoffield (2006, p. 275) used to smooth tidal predictions were based on work Doodson had conducted during the war, and these calculations would then be checked by a more senior computer - a "smoother" - who then used the figures to produce a graph. Scoffield (2006, pp. 225-228) estimated that predicting tides for one port took several people four days or a total of 30 person hours. As mechanical tidal predictors were still in use during the 1960s, the work

\footnotetext{
${ }^{39}$ Doodson to Galloway, 22 January 1918, Doodson papers.

${ }^{40}$ Doodson to Galloway, 4 February 1918, Doodson papers.

${ }^{41}$ Doodson to Galloway, 22 March, 5 April 1918, Doodson papers.

${ }^{42}$ Doodson's Personal Information File, section 8, RSA.

${ }^{43}$ Faculty of Science Minutes, 19 February 1923, S3025, LUA.

${ }^{44}$ See for example Doodson to Galloway, 1 July 1918, Doodson papers.
}

carried out by female computers in the late 1920s would have been similar.

TI acquired its first tidal predictor in 1924, with an additional machine purchased in 1929 (Woodworth, 2020). The tidal predictors were used alongside general purpose calculating machines. These calculators were a second-hand Tate Arithmometer bought in 1919, a second-hand Muldivo in 1921, two new Comptometers in 1921 and 1931, and a new electrical Monroe calculating machine in $1925^{45}$. At the time of TI's establishment, Messrs. Roberts \& Son were not using calculating machines for their tidal predictions (Proudman, 1920, p. 340) ${ }^{46}$. Both Andrew Warwick (1997) and Mary Croarken (2003, chaps. 1 and 2) have identified Pearson as an early adopter of calculating machines. Like another of Pearson's “disciples", Leslie John Comrie (18931950), who introduced mechanised computation at the Nautical Almanac Office (De Mol and Durand-Richard, 2016), Doodson appears to have reintroduced mechanised calculators into British tidal science. The adoption of such machines was part of a wider mechanisation of calculations and of the processing of data at this time, which has been linked by Jon Agar (2003, p. 177) to the type of modernisation and efficiency drive Alfred Booth led during the First World War. As industry and science required more and more tables of different sorts, including tide tables, they were increasingly produced using calculating machines, and much consideration was given to how to do the calculations in the most efficient manner (De Mol and Durand-Richard, 2016). The photograph in Fig. 1 portraying TI as an efficient and orderly scientific computation office is likely to have been staged for promotional literature or a journal article.

\subsection{Tl's arguments for funding}

Proudman now explicitly accepted that his 1918 claim that tidal predictions were good enough was actually incorrect. However, many other people still thought predictions were good enough. This can be exemplified by responses to a paper Warburg presented to the Royal Geographic Society in 1919. One person, a Mr. E. C. Barton, expressed "shock to learn that the harmonic methods have fallen into such disrepute". The chairman of the talk, the geologist Sir Aubrey Strahan (1852-1928), was surprised at the need for "extreme accuracy" in tidal predictions and questioned the value of working with errors in periodic tidal predictions when meteorological factors could not be predicted (Parry et al., 1919, p. 329).

To justify TI's existence, its research programme, and its funding, Proudman and Doodson needed to disparage existing methods of harmonic analysis and demonstrate the

\footnotetext{
${ }^{45}$ Proudman to Roberts, 3 October 1935, D/BO 3/3/1, MMM North Street.

46 "Methods, staff, etc.", part of Minute from Warburg to Hydrographer, 28 September 1921, in HYD 587/1921, within H 4434.23, UKHO.
} 


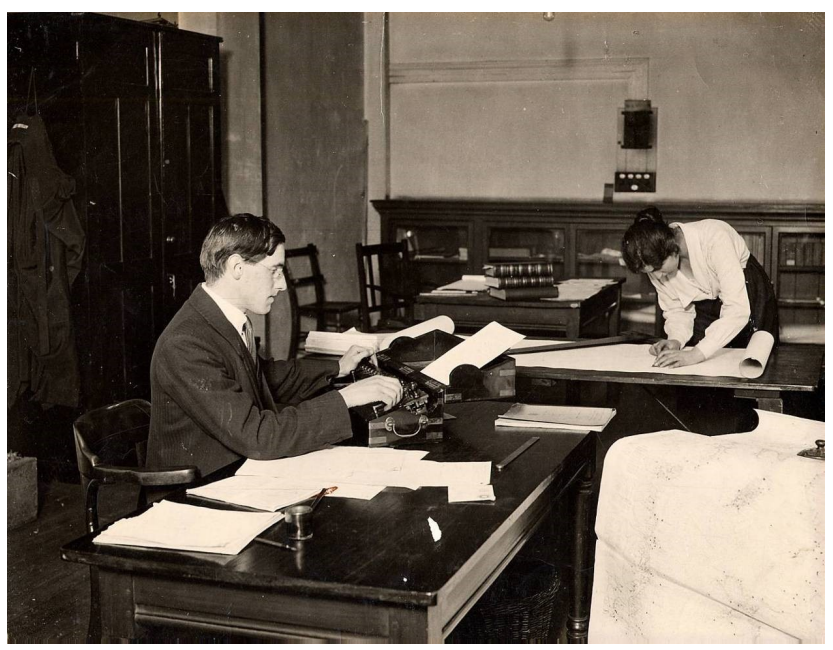

Figure 1. Doodson and one of the computers, Mrs. Dennis, in TI's room in the Holt Physics Laboratory on the university campus. Photograph used by permission of the National Oceanography Centre.

method was now insufficient for the needs of seafarers. In official reports to BAAS, Proudman and Doodson used a strong rhetoric linking trust to accuracy, arguing that predictions at that time were inaccurate and not trustworthy and that further work by scientists - i.e. themselves - was needed on predictions. Proudman declared it still remained to be determined how well the harmonic method could predict the astronomical tide and that comparisons of harmonic constants obtained from 10 separate years of data from one port (Bombay) had shown large "deviations" year to year for the smaller tidal constituents (Proudman, 1920). Doodson claimed it was a well-known fact that periodic tide predictions were not "accurate enough": "there are periodic or systematic differences in height and time of high water which are sufficiently serious in many cases to cause distrust ... the distrust has led in many cases to the complete abandonment of the method of harmonic prediction" Doodson (1920, p. 321).

Doodson's work on the practices and technologies of calculation involved in tidal predictions meant he could manage a larger number of calculations than had been possible for Thomson, Darwin, and other earlier tidal analysts (Doodson, 1922, p. 218), as explained by Woodworth (2020; see also Carlsson-Hyslop, 2015). These practices and technologies were used to rework the earlier version of the harmonic theory, using mathematical analysis techniques learnt from former Cambridge students during his studies at Liverpool University, combined with computational analysis of tidal data (Doodson, 1924), using techniques developed in mathematical laboratories in London during the war. Doodson linked calculations with theory, amending both to produce predictions that were closer to observations by including more of the variation in the data.

\section{A turning point for Tl: 1923}

These arguments and the work came together in 1923 to argue for further support from the shipping industry. By 1923, the Booths' funding was coming to an end. Therefore Proudman and Captain F. W. Mace, MDHB's Marine Surveyor and a member of TI's governing committee, prepared a funding bid to be presented to the Liverpool Steamship Owners' Association (LSOA) in April by Charles Booth and Charles Livingston, members of both LSOA and TI's governing committee. Formed in 1858 to lobby MDHB but quickly becoming nationally active, LSOA included the leading liner companies and has been described as "who's who" of both the Liverpool and national shipping scenes 47 . Taking a strong free trade/free sea stance, LSOA argued for equal access for all ships to all ports and against taxation and state interventions in shipping (Powell, 1958). It represented the commercial interests of the shipping industry, especially large companies and deep sea liner companies, in other words, those shipping companies most likely to use large ships with potentially deep draught, thus even more sensitive to the depth of water than smaller ships.

The funding bid to LSOA declared that present predictions were "susceptible to much improvement" and "[i]n spite of the great increase in the size of ships little advancement in the accuracy of tidal prediction has been made for forty years". To improve this situation a permanent research institute was said to be necessary. Providing examples of TI's early work, such as how their work had led to the "discovery" of a particular shallow water effect that could affect Liverpool's tides by nine inches, the appeal stated that support was now needed to enable TI to solve "problems of dock, harbour, river and coastal engineering" 48 . The appeal was successful. From 1923 until at least 1930, LSOA "unanimously" provided TI with grants. These decreased as TI's other income increased: the initial GBP 1200 in 1923 had been reduced to GBP 250 by May $1928^{49}$.

\subsection{MDHB and governance of TI}

During the first decade of TI's existence its governance structure was in constant flux. Though there had always been a strong contingent of shipping men, academic representatives had initially dominated TI's governing committee. This

\footnotetext{
${ }^{47}$ Maritime Archives and Library, Information Sheet 51, Liverpool Steamship Owners' Association (LSOA), https://www.liverpoolmuseums.org.uk/artifact/liverpoolshipowners-association, last access: 21 June 2020.

48 "Tidal Institute," Appeal attached to LSOA General Minutes, part 2: 1920-1964, (illegible date) April 1923, Vol. 29, D/SS/2/4, MMM.

${ }^{49}$ No conditions appear to have been attached to the grants. LSOA General Minutes, part 2: 1920-1964, 17 July 1923, Vol. 29; and LSOA General Minutes, part 2: 1920-1964, 21 May 1928, Vol. 36, D/SS/2/4, MMM. Also TI's ledger, S2147, LUA.
} 
changed in 1923, when MDHB and the university formed the Joint Committee to govern TI and Liverpool Observatory.

The MDHB had been charged by Parliament to maintain an observatory since the mid-nineteenth century. Initiated in 1845 and responsible for astronomical, seismographic, and meteorological measurements in Liverpool, as well as chronometer testing, Liverpool Observatory had moved to Bidston Hill on the Wirral peninsula in 1864. Following a dramatic increase in students following the First World War, the university needed to save money (Kelly, 1981, pp. 188 and 245), and in December 1922 it approached MDHB to discuss "the possibility of closer co-operation between the board and the university in the administration and activities of [the observatory and TI], on the grounds both of usefulness and economy". In return MDHB suggested that they and the university should set up the Joint Committee, governing both TI and the observatory, and also offered the university use of the observatory building free of rent, stating that the board would continue to maintain the building "in good and sufficient repair" $" 50$.

The Joint Committee consisted of 10 members: 5 appointed by the university, 5 appointed by MDHB. The university representatives actually included Charles Booth, as well as Harold Warburg (representing the Admiralty). This meant that the numerical advantage was now with shipping men, if Charles Booth and Harold Warburg are counted as such. Despite this dominance by shipping men, TI continued to combine work on analysis and predictions with theoretical work published in academic journals (Doodson, 1924, 1928a, b; Proudman and Doodson, 1924, 1927).

Now TI also began to sell their predictions. Holden's Almanack, based in Liverpool, commissioned TI to produce tidal predictions for Liverpool. At this time tidal predictions were published not only by Hydro in the Admiralty Tide Tables, but also in nautical almanacs published by the HM Nautical Almanac Office and by commercial publishers. These nautical almanacs contained tables (e.g. of tidal predictions and astronomical information) and other information used by sailors to navigate. The information was either compiled from a range of sources (including Hydro) or written and computed by staff employed directly by the publishers.

\subsection{State and naval patronage}

Starting in 1921, TI received grants from DSIR for 3 years. An initial application was made to DSIR in the early summer of 1920. DSIR's standard practice was to give a "pound for pound" grant equal to money raised from industry or other sources (Varcoe, 1974; Rose and Rose, 1969) and TI adjusted their application to comply with this. DSIR then consulted other departments, including the Admiralty, and with their

\footnotetext{
${ }^{50}$ MDHB Finance Committee Minutes, 5 December 1922, MDHB MP/10/42, MMM.
}

support requested a grant of GBP 600 from the Treasury ${ }^{51}$. The 1923/24 withdrawal of state funding, to be replaced by backing from the shipping industry, had been intended from the start, with DSIR stating their grant was intended to help TI do work that would "secure to the Institute a full measure of support from the shipping firms and other bodies interested" 52 .

Although the grant was ostensibly funded by the civil state, it was only awarded following support from the Admiralty; in a sense this was naval patronage by proxy. Those within the Admiralty contacted by DSIR consulted the Hydrographer, who in turn consulted Warburg. Warburg's response provides an example of the distance between Hydro and TI at this point. Claiming there had been a dramatic increase in tidal work since Hydro's Tidal Branch had been established in 1912, Warburg argued the best way to meet this demand would be a tidal prediction section within Hydro. He then went on to list institutions and individuals who conducted tidal work, not just Hydro and TI, but also Manchester University, the National Physical Laboratory, the Ordnance Survey, Messrs. Roberts \& Son, and a number of private individuals. Warburg saw no "general reason" why TI should be picked out for preferential treatment from these institutions and favoured a "properly equipped Tidal Branch" or further development of the work at NPL above subsidising "non-official investigations" 53 . Although Warburg then stated TI should be awarded a grant, he also stipulated this should be with the condition that their research programme reflect Hydro's priorities. The Admiralty thus requested that TI focus on specific areas such as "the investigation and elimination of errors in harmonic tidal predictions and predicting machines" 54 .

Hydro was again concerned with the quality of the predictions they had bought from Messrs. Roberts \& Son ${ }^{55}$. By 1923, contact between TI's researchers and Hydro had strengthened to the extent that Warburg claimed Proudman regularly wrote to him informally about developments ${ }^{56}$. TI had not been mentioned as a potential alternative source of predictions during the debate regarding Messrs. Roberts \& Son in 1920, but in 1923 Roberts' predictions contained large errors for the last 4 months of 1924 for four ports, including London and Liverpool. The predictions for London were in

\footnotetext{
${ }^{51}$ DSIR 36/13/4 "University of Liverpool, Tidal Institute, Grantin-Aid 1920-21”, NA.

${ }^{52}$ Report of the Committee of the Privy Council for Scientific and Industrial Research for the Year 1923-24. Cmd. 2223, HMSO, London, 1924, p. 34, and Report of the Committee of the Privy Council for Scientific and Industrial Research for the Year 192021. Cmd. 1491, HMSO, London, 1921, p. 68.

${ }^{53}$ Minute by Warburg, 26 August 1920, HD 1472/20, UKHO.

${ }^{54}$ Admiralty to Secretary, 8 October 1920, DSIR 36/13/4 "University of Liverpool, Tidal Institute, Grant-in-Aid 1920-21”, NA.

${ }^{55}$ Documents in file HYD 587/1921, within file H4434/23, UKHO.

${ }^{56}$ Report to Hydrographer, 26 June 1923, H 4038/23, UKHO.
} 
print in the US before these errors were identified, requiring Hydro to make profuse apologies to their US counterpart ${ }^{57}$. At the same time, TI had compared their new predictions for Liverpool (part of their own research and commissioned for Holden's Almanack) with Messrs. Roberts \& Son's. Having identified an error, they immediately sent a letter to Hydro enclosing comparisons along with examples of their calculation practices to demonstrate their "exhaustive and satisfactory tests ... of the accuracy of our work" 58 .

Warburg then produced a report listing recent mistakes by Messrs. Roberts \& Son and argued that the firm made too many mistakes in their calculations and did not check their work sufficiently: rather than their prediction method, it was their practices of calculation he deemed too unreliable. Warburg declared that these issues meant the question of finding an alternative source of predictions should be reopened. In addition, while there had been only two options available in 1920, Messrs. Roberts \& Son or calculating tidal predictions in-house, there was now a third: commissioning predictions from $\mathrm{TI}^{59}$.

Proudman had casually informed Warburg that TI was considering purchasing a tidal predictor machine to start producing predictions, and Warburg now wrote to the Hydrographer that while commissioning predictions from TI was likely to "end for all time any hope" of a tidal-predicting branch at the Admiralty, he believed this was the way forward, as it would involve "the two leading scientific authorities in the country on modern tidal work" as well as "the good name of the University". The university connection was crucial for Warburg: being neither state nor private would guard against the possibility of sudden changes in price and availability that occurred when dealing with private businesses while also avoiding the "prejudice" he believed a state equivalent at Hydro would face. Having apparently given up hope of extending his own tidal branch, Warburg presented TI as the relatively cheap solution ${ }^{60}$, an assessment reinforced by Hydrographer Learmonth: "all the advantages to be expected from the provision of an Admiralty machine will be obtained without the disadvantage of expenditure from Government funds" $" 61$.

\footnotetext{
${ }^{57}$ Minutes and correspondence in $\mathrm{H} 4038 / 23$, UKHO.

${ }^{58}$ These checks were done by calculating the mean of the interval between the time of upper transit at Greenwich (an astronomical event) and that of the predicted high-water times. The mean interval of TI's predictions was then compared with the mean intervals calculated using other fast methods. If the different means were close, as in the case of TI's calculations, this indicated that the calculations had been done correctly. Doodson to Warburg, 7 June 1923, H 4038/23, UKHO.

${ }^{59}$ Memorandum to Hydrographer, by Warburg, 26 June 1923, H 4038/23, UKHO.

${ }^{60}$ Memorandum to Hydrographer, by Warburg, 26 June 1923, H 4038/23, UKHO.

${ }^{61}$ Minute by Learmonth, Hydrographer, 16 July 1923, H 4434/23, UKHO.
}

Later that year, after the formation of the Joint Committee of the university and MDHB, Proudman formally requested Hydro to consider purchasing predictions from $\mathrm{TI}^{62}$. Hydro immediately offered not only to give TI all their new work on analysis and predictions, but also to gradually transfer all their existing out-sourced work to $\mathrm{TI}^{63}$. They did however make a number of conditions: that TI should provide a detailed technical description of the machine they proposed to purchase, various financial reassurances, and a commitment of permanence. These demands were met ${ }^{64}$, although the university's first attempt at providing a commitment of permanence was deemed unsatisfactory. The final resolution, prescribed by Hydro, declared that TI must give 3 years notice at normal rates if they wanted to cease providing predictions $^{65}$.

As part of the discussions regarding the creation of the Joint Committee to govern TI and the observatory and the informal discussions regarding their potential purchase of predictions, Hydro had been invited to send a representative. Though initially hesitant, they decided that a representative on the governing committee would afford them a desirable level of influence ${ }^{66}$. Warburg became Hydro's first representative in 1924, sitting as one of the five representatives selected by the university ${ }^{67}$.

\subsection{The merger of $\mathrm{TI}$ and the Liverpool observatory}

Soon after the introduction of the Joint Committee in 1923, debates began about a complete merger of TI and the observatory at Bidston, prompted by plans to install the new tidal predictor at the observatory ${ }^{68}$. Although the merger did not go ahead - the elderly director of the observatory, William Plummer (1849-1928), had no pension and could not retire ${ }^{69}$ - co-operation increased, with TI also using the observatory building ${ }^{70}$.

\footnotetext{
${ }^{62}$ Proudman to Hydrographer, 27 June 1923, H 4434/23, UKHO.

${ }^{63}$ Learmonth (Hydrographer) to Director of TI, 6 September 1923, H 4434/23, UKHO.

${ }^{64}$ Notes and correspondence in $\mathrm{H} 4434 / 23$, UKHO. The TI subsequently purchased a tidal predictor (the Bidston Kelvin Machine) at a cost of around GBP 1500, with funds donated mainly from various shipping men and companies (GBP 1200) but also BAAS (GBP 300); see Tidal Institute Ledger, S2147, LUA.

${ }^{65}$ Learmonth (Hydrographer) to Registrar, 15 November 1923, H 4434/23, UKHO.

${ }^{66}$ Minute by Warburg, 9 October 1923, H 4434/23, UKHO.

${ }^{67}$ Notes and correspondence in H 4434/23, UKHO. See also University Council Minutes, 21 January 1924, S2222, LUA.

${ }^{68}$ Minutes of the Marine Committee, 14 July 1924, p. 475, File M.P.13.18, MDHB Archive, MMM.

${ }^{69}$ Notes by Warburg in $\mathrm{H} 835 / 27$ and $\mathrm{H}$ 8761/23, UKHO.

${ }^{70}$ See for example LSOA General Minutes, part 2: 1920-1964, 17 July 1923, Vol. 29; and LSOA General Minutes, part 2: 1920 1964, 21 May 1928, Vol. 36, D/SS/2/4, MMM.
} 
Following Plummer's death in the spring of 1928, an agreement was slowly negotiated to merge the two institutions in early 1929 as the Liverpool Observatory and Tidal Institute (LOTI) (Nature News Item, 1928). The new governing committee paid salaries and other running costs, such as electricity and equipment maintenance, while also fulfilling MDHB's legal obligations to provide observatory services to the port ${ }^{71}$. The university was on the governing committee and paid a small grant to TI, while MDHB contributed more substantially, both financially and in kind, by maintaining the observatory building it lent TI without charge (Scoffield, 2006, p. 175). The new LOTI Committee was very similar to the committee that had previously governed TI, now with 12 members and a continued dominance of shipping men ${ }^{72}$.

This dominance was the most contentious issue during merger negotiations (LOTI, 1930, p. 2). As the board's duties regarding the observatory were set down by an Act of Parliament, MDHB's solicitors insisted the committee chair must always be from MDHB and have a deciding vote. This led to heated discussions, which, according to Warburg, were about ensuring "that the local prestige of neither side will suffer" 73 . In the end MDHB, who were providing the majority of the financial support, got their way, giving the shipping industry a deciding vote on TI's governing committee. While the observatory was somewhat short of cash and unlikely to find new ways of raising revenue ${ }^{74}$, TI's income from tidal predictions was steadily increasing and, following the agreement with Hydro, was expected to continue doing so.

Proudman later argued that TI gained space, finance, prestige (by virtue of being associated with "a prominent building"), and stability in governance from the merger ${ }^{75}$. The spatial aspect of Proudman's argument is supported by his request to the Joint Committee for the use of an additional room at the observatory by TI staff in late 1927, as the "housing accommodation of the Institute" was "inadequate". This is likely to have been due to the increased number of predictions TI was carrying out and the resulting employment of more staff. All TI's practical work could now take place on one $\operatorname{site}^{76}$. Doodson became director of the observatory, providing access to the substantial financial contribution MDHB gave to the observatory and enabling TI to take on both an astronomically focused assistant to provide observatory ser-

\footnotetext{
${ }^{71}$ Liverpool Observatory Joint Committee, Minutes, 5 November 1928, D/BO 1/1/2, MMM - North Street.

${ }^{72}$ Minutes of the Finance Committee, 14 November 1928, p. 129 , file 46, MDHB Archive, MMM.

${ }^{73}$ Minute by Warburg, 8 November 1928, H7452/28, UKHO.

${ }^{74}$ Minutes of the Marine Committee, 22 October 1923, p. 398, M.P.13.18, MDHB Archive, MMM.

${ }^{75}$ Proudman to Vice-Chancellor Mountford, 29 October 1959, P744/5, LUA.

${ }^{76}$ Vice-Chancellor to Hydrographer, 4 December 1928 , H7452/28, UKHO.
}

vices for the port and a tidal assistant to conduct routine prediction work ${ }^{77}$.

\section{The role of tidal predictions in Tl's finance, 1920s-1950s}

By mid-December 1923, TI was receiving its first instructions from Hydro to provide predictions under the new arrangement between the two organisations ${ }^{78}$. The number of predictions TI produced overall increased gradually, boosted at the end of the 1920s when the Roberts family sold their tidal predictor machine and business to TI after the death of Mr Roberts senior (Scoffield, 2006). Another upturn occurred during the Second World War, when sets of predictions increased from about 80 for 1940 to over 150 for 1946. By the late 1950s, TI was providing what was called "full" predictions using the harmonic method with times and heights of both high and low waters for over 180 ports known as "standard ports", as well as a substantial number of less comprehensive predictions for "secondary ports", making TI one of the largest providers of tidal predictions in the world $^{79}$.

Table 2 shows the gradual increase in income from what is described in TI's ledger and accounts as "commercial work" as well as the contributions from the primary components of this work: tidal analysis and predictions ${ }^{80}$. Commercial work included tidal predictions and analyses as well as income from providing meteorological information, "special tidal work", and other small income streams, such as from tests of instruments or sale of publications. The table also indicates the increase in TI's reserve account between 1929 and 1957, indicating the generally healthy state of finances. TI's

\footnotetext{
${ }^{77}$ See various notes and minutes by Warburg in $\mathrm{H} 8761 / 23$ and $\mathrm{H}$ $835 / 27$, UKHO

${ }^{78}$ Notes and correspondence in $\mathrm{H} 4434 / 23$, UKHO.

${ }^{79}$ Numbers are for "full" predictions made for "standard ports" prepared using the harmonic method and do not include less comprehensive predictions prepared for almanacs using a simpler method. Predictions were made 1 or 2 years in advance, so the numbers represent work done a couple of years earlier. Based on information in LOTI's Centenary Report and Annual Reports 1940-1945 and on LOTI's Annual Reports from the period 1946-1960 (LOTI, 1946, 1947, 1950, 1952, 1953, 1959, 1960), published in Liverpool by the University of Liverpool (after 1958 published by C. Tinling and Co. Ltd.). It is difficult to give an exact number for the less comprehensive predictions, but Scoffield (2006, p. 216) quotes 600 almanac predictions per year in the late $1950 \mathrm{~s}$.

${ }^{80}$ Accounts 1929-38, D.BO 2/1/3/1 and Accounts 1942-57 (including figures from 1941), D.BO 2/1/3/2, MMM - North Street. Either side of these dates the accounts are either not available or in a format that is not directly comparable, e.g. displayed in a different format and using a different financial year before 1929. The accounts for 1951 and 1952 are missing, though figures for 1952 were taken from the accounts for 1953. Accounts are also missing from 1939 and 1940, for which the commercial income has been calculated from the revenue account summary, in ledger, S2148, LUA.
} 
overall financial balance was so strong that between 1938 and 1951, a substantial part of a grant they received from MDHB was repaid ${ }^{81}$. The commercial work paid for itself and often made a profit. It made TI relatively secure financially, though they also continued to receive annual payments from the university (GBP 50 until 1951, GBP 500 thereafter) and MDHB (GBP 1500).

Although TI's prediction work was commercial in the sense that it brought income to the institute, the predictions themselves cut across any boundaries between military, civil state, and industry. In 1933, TI listed their clients for analyses and full predictions as shown in Table 3.

It is noticeable that many though not all of TI's clients were from within the British Empire. Because TI's workers generally recorded type of prediction and not type of client, it is difficult to get a sense of relative importance. However, a rare analysis of TI's prediction income by region in 1956 gives us an idea. As Table 4 illustrates, only $14 \%$ of TI's income from tidal prediction came directly from the Admiralty. A fifth of predictions was for named imperial countries (Canada, Australia, and New Zealand), likely to have been administered by the Admiralty. A third of TI's income came from almanacs, while "elsewhere" accounted for another third ${ }^{82}$.

The interest of so many of TI's funders in tidal analysis and predictions had an obvious impact on TI's research programme. They continued to carry out work in this area, for example making improvements to tidal predictor machines. They also worked on non-harmonic methods for predicting tides, for example where the tidal data only listed high and low water heights and times (Doodson, 1928c; LOTI, 1945, 1946, pp. 5-6, 1950). Further publications resulted, both in academic journals (e.g. Doodson, 1937) and e.g. the $A d$ miralty Manual of Tides, cowritten by Doodson and Warburg (1941), which summarised a non-harmonic method of predicting tides that they had developed, known as the Admiralty method. The research programme also included much other work, such as the continuation of theoretical work led by Proudman, the production of cotidal charts published by the Admiralty (Doodson and Corkan, 1933), and the assessment of hydraulic models for simulating tides ${ }^{83}$.

\footnotetext{
${ }^{81}$ In 1938, the 1929 LOTI merger agreement was amended to allow part of TI's surplus to be returned to MDHB, as long as the Reserve Fund was maintained at an "adequate" level, by which was meant GBP 2000 together with the credit of the Income and Expenditure account. Minutes, LOTI Committee, 12 December 1938, D/BO/2/1/3/2, MMM - North Street.

${ }^{82}$ Other figures from the 1950 s confirm that about a third of TI's income from predictions came from almanacs, "Liverpool Observatory and Tidal Institute", D.BO. 2/1/3/2, MMM - North Street.

${ }^{83}$ See correspondence in Box 129, Bidston Archive, Liverpool World Museum, National Museums and Galleries on Merseyside.
}

\section{Conclusions}

In this article I have detailed the establishment of TI shortly after the First World War and the institute's early years. The initial patronage of TI represented a combination of academic and industrial interests, with the Navy providing TI with the resource of research ideas and pointers. While TI's heavy reliance on industrial patronage was common at Liverpool University, as at similar universities in England at the time, it makes TI a relatively unusual case in the history of physical oceanography, because of its focus on naval patronage. The First World War boosted interest in tides and oceanography generally, as the supply of tidal predictions was cut off, traffic congestion increased in major ports, the size of ships increased, and submarines were introduced.

In regard to debates about the role of the First World War in increasing state involvement in the funding of scientific research, such an increase was not obviously evident in TI's establishment. The BAAS plans for the Geodetic Institute were not given state funding and TI had to rely on industrial funding. In TI's case, the question posed by historians needs to be framed differently. It was not so much whether the First World War led to increased state support of science in general, but whether it led to increased interest in and support of particular types of research. This it certainly did: the TI that eventually resulted had a research programme focused on tidal predictions, rather than the more theoretical agenda suggested for the proposed Geodetic Institute. This was prompted by Hydro's interests and those of TI's patrons, the Booth brothers, which in turn were linked to a war-driven efficiency agenda. Unlike a traditional patron, Hydro initially neither provided finance, like the Booths, nor other resources such as building space, like the university, but it did provide assistance with research topics. The adaptable Proudman shifted his institution-building strategies, his priorities, and his opinions to meet needs and demands.

The three corners of TI's hybrid, triangular patronage structure were industrial, naval, and academic. The share of TI's funding from the sale of tidal predictions - partly to industrial actors such as almanac publishers, but importantly to Hydro, providing a strong link with the Navy once established - increased over the years, but TI still required other support. The industrial patrons - Liverpool shipping owners, primarily through MDHB and LSOA - became key, providing substantial funding and a physical home. While their financial assistance was limited, Liverpool University provided a link to academic science - an important point in TI's favour from Hydro's perspective - and was involved in TI's governance.

This hybrid patronage impacted on TI's work, much of which was focused on producing and increasing the accuracy of tidal predictions. At the same time, its identity was as a scientific institution where academic research was conducted and published in scientific journals, while commer- 
Table 2. Some of TI's income streams, the sum they returned to MDHB between 1938 and 1951, and the balance of TI's reserve account, all in pounds by year.

\begin{tabular}{|c|c|c|c|c|c|c|c|}
\hline Year & $\begin{array}{l}\text { Number of sets } \\
\text { of predictions }\end{array}$ & $\begin{array}{r}\text { Number of sets } \\
\text { of analyses }\end{array}$ & $\begin{array}{l}\text { Total income from } \\
\text { all commercial work }\end{array}$ & Grants & $\begin{array}{r}\text { Total } \\
\text { income }\end{array}$ & $\begin{array}{r}\text { Amount returned } \\
\text { to } \mathrm{MDHB}\end{array}$ & $\begin{array}{r}\text { Balance of } \\
\text { reserve account }\end{array}$ \\
\hline 1929 & 775 & 312 & 1781 & 1675 & 3456 & & 1482 \\
\hline 1930 & 1225 & 255 & 1869 & 1650 & 3519 & & 1858 \\
\hline 1931 & 1246 & 101 & 1867 & 1550 & 3417 & & 2299 \\
\hline 1932 & 1174 & 173 & 1530 & 1550 & 3080 & & 2254 \\
\hline 1933 & 1158 & 220 & 1593 & 1550 & 3143 & & 2288 \\
\hline 1934 & 1103 & 76 & 1406 & 1550 & 2956 & & 2353 \\
\hline 1935 & 1246 & 196 & 1779 & 1550 & 3329 & & 2283 \\
\hline 1936 & 1361 & 327 & 1988 & 1550 & 3538 & & 2381 \\
\hline 1937 & 1557 & 223 & 1973 & 1550 & 3523 & & 2481 \\
\hline 1938 & 1540 & 342 & 2155 & 1550 & 3705 & Unknown & 2461 \\
\hline 1939 & 1803 & & 2358 & 1550 & 3908 & Unknown & \\
\hline 1940 & 2539 & & 3275 & 1550 & 4825 & Unknown & \\
\hline 1941 & 2067 & 58 & 2611 & 1550 & 4161 & Unknown & 4278 \\
\hline 1942 & 2337 & 219 & 2631 & 1550 & 4181 & 500 & 4476 \\
\hline 1943 & 2619 & 97 & 3039 & 1550 & 4589 & 500 & 4894 \\
\hline 1944 & 3049 & 169 & 3338 & 1550 & 4888 & 1000 & 5020 \\
\hline 1945 & 4680 & 648 & 5965 & 1550 & 7515 & 1000 & 5265 \\
\hline 1946 & 3521 & 338 & 4220 & 1550 & 5770 & 1250 & 7416 \\
\hline 1947 & 3626 & 642 & 5079 & 1550 & 6629 & 500 & 7695 \\
\hline 1948 & 3513 & 1624 & 5782 & 1550 & 7332 & 500 & 8294 \\
\hline 1949 & 3889 & 581 & 4992 & 1550 & 6542 & 500 & 9378 \\
\hline 1950 & 4770 & 416 & 5850 & 1550 & 7400 & 500 & 6520 \\
\hline 1951 & & & & & & Unknown & \\
\hline 1952 & 5382 & 362 & 6547 & 2000 & 8547 & & \\
\hline 1953 & 6504 & 386 & 7915 & 2000 & 9915 & & 6793 \\
\hline 1954 & 6831 & 1152 & 8325 & 2000 & 10325 & & 7952 \\
\hline 1955 & 7021 & 390 & 7909 & 2000 & 9909 & & 10213 \\
\hline 1956 & 7175 & 370 & 8295 & 2000 & 10295 & & 8796 \\
\hline 1957 & 8305 & 638 & 10029 & 2000 & 12029 & & 9258 \\
\hline
\end{tabular}

Table 3. TI's clients (LOTI, 1933).

\begin{tabular}{lll}
\hline Hydro & Donsink Observatory, Co. Dublin & Agent General for New South Wales \\
\hline $\begin{array}{l}\text { Anglo Saxon Petroleum Co. } \\
\begin{array}{l}\text { Corporation of Bristol } \\
\text { L'Adminstration des Ponts et }\end{array}\end{array}$ & Ministère de la Marine, Paris & Queensland Government \\
Chaussées, Belgium & Harwich Harbour Conservancy Board & $\begin{array}{l}\text { Southampton Harbour Board } \\
\text { Agent General for South Australia }\end{array}$ \\
$\begin{array}{l}\text { Port Director, Basra, Mesopotamia } \\
\text { Canadian Hydrographic Service }\end{array}$ & Survey of India and Hydrographer & Sydney Harbour Trust \\
$\begin{array}{l}\text { Crown Agents for the Colonies } \\
\text { Colonial Office }\end{array}$ & $\begin{array}{l}\text { Port of London Authority } \\
\text { London and North Eastern Railway Co. }\end{array}$ & $\begin{array}{l}\text { Agent General for West Australia } \\
\text { High Commissioner for New Zealand }\end{array}$ \\
\hline
\end{tabular}


Table 4. TI's income from predictions by region and type of client (D.BO 2/1/3/2, MMM - North Street).

\begin{tabular}{|c|c|c|}
\hline \multicolumn{3}{|c|}{ Analysis of prediction income 1956 , in pound } \\
\hline Admiralty & 1000 & $14 \%$ \\
\hline Canada & 752 & $10 \%$ \\
\hline Australia & 540 & $8 \%$ \\
\hline New Zealand & 168 & $2 \%$ \\
\hline Elsewhere & 2440 & $34 \%$ \\
\hline Sub-total & 4900 & $68 \%$ \\
\hline Almanacs & 2275 & $32 \%$ \\
\hline Total & 7175 & \\
\hline
\end{tabular}

cial work was "just" income ${ }^{84}$. To TI this setup, as "a scientific institution owned and run by businessmen [and the Navy]" 85 , remained a viable way to fund research for several decades. During his retirement dinner in 1960, Doodson was described by an MDHB representative as "perhaps the only man whoever conducted scientific research at a profit" ${ }^{\prime \prime 6}$. While partly a simple flattering comment, it also summarises Doodson's, and TI's, balancing and combining of science with commerce.

TI's strong dependence on the shipping industry for patronage contrasts with the existing literature's emphasis on military support for physical oceanography (Hamblin, 2005; Weir, 2001; Doel, 2003; Mukerji, 1989). It was support from the shipping industry that enabled TI to carry out the work that was then put into practice to generate income by producing predictions for Hydro and other clients. While BAAS, Liverpool University, and Hydro via DSIR also supported this work, they did so only after the Booths' funding had established TI, making the support of academic and state actors dependent on TI's earlier industrial patronage. In addition, TI's initial research programme emphasised the production of tidal analysis and predictions for merchant and naval shipping to suit their shipping industry patrons, after which the concerns of Hydro gradually increased in importance. While naval patronage was important to TI, other sources of patronage were at least as important, something which could be further investigated in other case studies by historians of oceanography. In addition, paying detailed attention to the patronage structure of research institutes such as TI provides a more detailed picture of how patronage from different sources can interact and depend on each other. While

\footnotetext{
${ }^{84}$ For example, in the annual report of TI for 1945, Doodson and Proudman emphasised that TI's "importance" came not from the analyses and predictions, but from its academic tidal research (LOTI, 1945, p. 13).

${ }^{85}$ Proudman to Mountford, 29 October 1959, P744/5, LUA.

${ }^{86}$ While this was clearly a flattering remark, given the healthy bank balance of TI in the 1950s, see Table 2, as well as the tone of the speech I do not think this was meant only as a joke. Mr. Paton's speech, folder Retirement, Doodson Papers.
}

TI, through its contract with Hydro, became a contractor to David Edgerton's (2006) warfare state, one reason Hydro favoured TI was its academic position: neither state nor industry, neither public nor private. The relationship between Hydro and TI developed as a result of opportunistic negotiations on both sides, not in response to a unified policy from "the state".

Data availability. The underlying data for this article are papers in a variety of archives, cited throughout the text. The references provide sufficient details to locate the original document in the archive.

Archival material is referenced in footnotes. Abbreviations for the locations of archives used in these footnotes are as follows.

- Doodson papers: Liverpool World Museum, National Museums and Galleries on Merseyside, Liverpool

- NA: The National Archives, Kew, London

- LUA: Liverpool University Archive, Liverpool University Sydney Jones Library, Liverpool

- MMM: Merseyside Maritime Museum, National Museums and Galleries on Merseyside, Liverpool. The addition of North Street signifies that the material is held in their reserve store.

- RSA: Royal Society Archive, London

- UKHO: United Kingdom Hydrographic Office Archive, Taunton

Competing interests. The author declares that there is no conflict of interest.

Special issue statement. This article is part of the special issue "Developments in the science and history of tides (OS/ACP/HGSS/NPG/SE inter-journal SI)". It is not associated with a conference.

Acknowledgements. I am grateful for the editorial assistance of Joanna Baines. The article is based on research and text from my thesis which was developed further for two articles (CarlssonHyslop, 2010, 2015, 2016).

Financial support. The research for this article was done for a $\mathrm{PhD}$ funded by the UK Economic and Social Research Council.

Review statement. This paper was edited by Philip Woodworth and reviewed by Paul Hughes and Marie-José Durand-Richard. 


\section{References}

Agar, J.: The Government Machine: A Revolutionary History of the Computer, MIT Press, London, https://doi.org/10.7551/mitpress/3336.001.0001, 2003.

Carlsson-Hyslop, A.: An Anatomy of Storm Surge Science at Liverpool Tidal Institute 1919-1959: Forecasting, Practices of Calculation and Patronage, University of Manchester, $\mathrm{PhD}$ thesis, available at: http://nora.nerc.ac.uk/id/eprint/14623/ (last access: 12 July 2020), 2010

Carlsson-Hyslop, A.: Human computing practices and patronage: antiaircraft ballistics and tidal calculations in first world war Britain, Inform. Cult., 50, 70-109, https://doi.org/10.7560/IC50104, 2015.

Carlsson-Hyslop, A.: Patronage and practice in British oceanography: The mixed patronage of storm surge science at the Liverpool Tidal Institute, 1919-1959, Hist. Stud. Nat. Sci., 46, 270-312, https://doi.org/10.1525/hsns.2016.46.3.270, 2016.

Cartwright, D. E.: The historical development of tidal science, and the Liverpool Tidal Institute, in: Oceanography, the Past, edited by: Sears, M. and Merriman, D., Springer, New York, NY, https://doi.org/10.1007/978-1-4613-8090-0_23, 1980.

Cartwright, D. E.: Tides: A scientific history, Cambridge University Press, Cambridge, 1999.

Cartwright, D. E. and Ursell, F.: Joseph Proudman. 30 December 1888-26 June 1975, Biogr. Mem. Fellows Roy. Soc., 22, 319-333, https://doi.org/10.1098/rsbm.1976.0014, 1976.

Clarke, S.: Pure science with a practical aim: The meanings of fundamental research in Britain, circa 1916-1950, ISIS, 101, 285311, https://doi.org/10.1086/653094, 2010.

Croarken, M.: Astronomical labourers: Maskelyne's assistants at the Royal Observatory, Greenwich, 1765-1811, Notes Rec. Roy. Soc., 57, 285-298, https://doi.org/10.1098/rsnr.2003.0215, 2003.

Darwin, G. H.: Report of a committee for the harmonic analysis of tidal observations, in: Report of the Fifty-Third Meeting of the British Association for the Advancement of Science, Southport - 1833, September, John Murray, London, 1884.

Day, A.: The Admiralty Hydrographic Service, 1795-1919, Her Majesty's Stationery Office, London, 1967.

Deacon, M. B.: G. Herbert Fowler (1861-1940): The forgotten oceanographer, Notes Rec. Roy. Soc., 38, 261-296, https://doi.org/10.1098/rsnr.1984.0016, 1984.

De Mol, L. and Durand-Richard, M.-J.: Calculating machines and numerical tables - a reciprocal history, Hal-Lille3 [preprint], available at: https://hal.univ-lille3.fr/hal-01396846/ (last access: 12 July 2020), 2016

Doel, R. E.: Constituting the postwar earth sciences: The military's influence on the environmental sciences in the USA after 1945, Soc. Stud. Sci., 33, 635-666, https://doi.org/10.1177/0306312703335002, 2003.

Doodson, A. T.: Report on harmonic prediction of tides, in: Report of the Eighty-Eighth Meeting of the British Association for the Advancement of Science, Cardiff - 1920, August 24-28, John Murray, London, 1920.

Doodson, A. T.: To assist works on the tides, in: Report of the Eighty-Ninth Meeting of the British Association for the Advancement of Science, Edinburgh, 7-14 September 1921, John Murray, London, 1922.
Doodson, A. T.: Perturbations of harmonic tidal constants, Proc. R. Soc. Lon. Ser.-A, 106, 739, 513-526, https://doi.org/10.1098/rspa.1924.0085, 1924.

Doodson, A. T.: Tide-predicting machines, Nature, 118, 787-788, https://doi.org/10.1038/118787a0, 1926.

Doodson, A. T.: The analysis of tidal observations, Philos. T. R. Soc. S.-A, 227, 223-279, https://doi.org/10.1098/rsta.1928.0006, 1928a.

Doodson, A. T.: Application of numerical methods of integration to tidal dynamics, Geophys. J. Int., 1, 541-557, https://doi.org/10.1111/j.1365-246x.1928.tb05360.x, 1928b.

Doodson, A. T.: The analysis and prediction of tidal currents from observations of times of slack water, Proc. R. Soc. Lon. Ser.-A, 121, 72-88, https://doi.org/10.1098/rspa.1928.0183, 1928c.

Doodson, A. T.: Further comments on the 19-yearly tide, B. Geod., 55, 102-103, https://doi.org/10.1007/bf02539506, 1937.

Doodson, A. T. and Corkan, R. H.: The principal constituent of the tides in the English and Irish Channels, Philos. T. R. Soc. S.-A, 231, 29-53, https://doi.org/10.1098/rsta.1933.0002, 1933.

Doodson, A. T. and Warburg, H. D.: Admiralty Manual of Tides, H.M.S.O., London, 1941.

Dyson, F. W.: Meeting for the discussion of geophysical subjects, Wednesday, 1917 Nov 7, Observatory, 40, 444, 1917.

Edgerton, D.: Warfare State: Britain, 1920-1970, Cambridge University Press, Cambridge, 2006.

Gooday, G.: The Morals of Measurement: Accuracy, Irony, and Trust in Late Victorian Electrical Practice, Cambridge University Press, Cambridge, https://doi.org/10.1017/cbo9780511550690, 2004.

Hamblin, J. D.: Oceanographers and the Cold War: Disciples of Marine Science, University of Washington Press, London, available at: https://www.jstor.org/stable/j.ctvcwnft5 (last access: 12 July 2020), 2005.

Hartcup, G.: The War of Invention: Scientific Developments, 1914 18, Brassey's, London, 1988.

Hughes, P.: A Study in the Development of Primitive and Modern Tide Tables, PhD thesis, Liverpool John Moores University, 2005.

Hull, A.: Passwords to Power - a Public Rationale for Expert Influence on Central Government Policy-Making: British Scientists and Economists, c. 1900-c. 1925, PhD thesis, University of Glasgow, 1994.

Hull, A.: War of words: The public science of the British scientific community and the origins of the Department of Scientific and Industrial Research, 1914-1916, Brit. J. Hist. Sci., 32, 461-481, https://doi.org/10.1017/s0007087499003775, 1999.

Hyde, F. E.: Liverpool and the Mersey: An Economic History of a Port 1700-1970, David \& Charles, Newton Abbot, 1971.

John, A. H.: A Liverpool merchant house, being the history of Alfred Booth \& Company 1863-1958, George Allen \& Unwin Ltd, London, https://doi.org/10.4324/9781315019963, 1959.

Jones, J.: Science, Utility and the "Second City of the Empire": The Sciences and Especially the Medical Sciences at Liverpool University 1881-1925, PhD thesis, University of Manchester, 1989.

Kelly, T.: For Advancement of Learning: The University of Liverpool, 1881-1981, Liverpool University Press, Liverpool, 1981.

Lamb, H. and Proudman, J.: Preliminary report on tides and tidal currents, in: Report of the British Association for the Advancement of Science, 1918, London, London, John Murray, 1919. 
Liverpool Tidal Institute: Tidal Institute: First Annual Report, 1920, University of Liverpool, Liverpool, 1920.

LOTI: Annual Report 1930, University of Liverpool, Liverpool, 1930.

LOTI: Annual Report 1933, University of Liverpool, Liverpool, 1933.

LOTI: Centenary Report and Annual Reports (1940-1945), University of Liverpool, Liverpool, 1945.

LOTI: Annual Report 1946, University of Liverpool, Liverpool, 1946.

LOTI: Annual Report 1947, University of Liverpool, Liverpool, 1947.

LOTI: Annual Report 1950, University of Liverpool, Liverpool, 1950.

LOTI: Annual Report 1952, University of Liverpool, Liverpool, 1952.

LOTI: Annual Report 1953, University of Liverpool, Liverpool, 1953.

LOTI: Annual Report 1959, C. Tinling and Co. Ltd., Liverpool, 1959.

LOTI: Annual Report 1960, C. Tinling and Co. Ltd., Liverpool, 1960.

Love, A. E. H. and Glazebrook, R. T.: Sir Horace Lamb. 1849-1934, Obit. Notices Fellows Roy. Soc., 1, 375-392, https://doi.org/10.1098/rsbm.1935.0003, 1935.

Lubbock, J. W.: Discussion of tide observations made at Liverpool, Philos. T. R. Soc., 125, 275-299, https://doi.org/10.1098/rstl.1835.0017, 1835.

MacLeod, R. M.: Scientists, government and organised research in Great Britain 1914-16, Minerva, 8, 454-457, https://doi.org/10.1007/bf01553232, 1970.

MacLeod, R. M.: Retrospect: The British Association and its historians, in: The Parliament of Science: The British Association for the Advancement of Science, 1831-1981, edited by: MacLeod R. M. and Collins, P., Science Reviews, Northwood, 1-16, 1981.

MacLeod, R. M. and Andrews, E. K.: Scientific advice in the war at sea, 1915-1917: The Board of Invention and Research, J. Contemp. Hist., 6, 3-40, https://doi.org/10.1177/002200947100600201, 1971.

Mountfield, S.: Western Gateway: A History of the Mersey Docks and Harbour Board, Liverpool University Press, Liverpool, 1965.

Mukerji, C.: A Fragile Power: Scientists and the State, Princeton University Press, Princeton, https://doi.org/10.1515/9781400860241, 1989.

Nature News Item: Liverpool Observatory and Tidal Institute, Nature, 122, 979-980, https://doi.org/10.1038/122979b0, 1928.

Parry, J. F.: Meeting for the discussion of geophysical subjects, Wednesday, 1918 June 12, Observatory, 41, 283, 1918.

Parry, J. F., Roberts, H. W. T., Gheury, M. J., Barton, E. C., Strahan, A., Mr. Hinks, and Warburg H. D.: The Admiralty tide tables and North Sea tidal predictions: Discussion, Geogr. J., 53, 326-330, https://doi.org/10.2307/1779473, 1919.

Powell, L. H.: A hundred years on: History of the Liverpool Steam Ship Owners' Association, 1858-1958, Liverpool Steam Ship Owners' Association, Liverpool, 1958.

Proudman, J.: Report on harmonic analysis of tidal observations in the British Empire, in: Report of the Eighty-Eighth Meeting of the British Association for the Advancement of Science, Cardiff - 1920, August 24-28, John Murray, London, 1920.
Proudman, J.: Arthur Thomas Doodson, 1890-1968, Biogr. Mem. Fellows Roy. Soc., 14, 189-205, https://doi.org/10.1098/rsbm.1968.0008, 1968.

Proudman, J. and Doodson, A. T.: The principal constituent of the tides of the North Sea, Philos. T. R. Soc. S.-A, 224, 185-219, https://doi.org/10.1098/rsta.1924.0005, 1924.

Proudman, J. and Doodson, A. T.: On the tides in an ocean bounded by two meridians on a non-rotating earth, Geophys. J. Int., 1, 468-483, https://doi.org/10.1111/j.1365246x.1927.tb05391.x, 1927.

Proudman, J., Doodson, A. T., and Kennedy, G.: Numerical results of the theory of the diffraction of a plane electromagnetic wave by a perfectly conducting sphere, Philos. T. R. Soc. S.-A, 217, 279-314, https://doi.org/10.1098/rsta.1918.0008, 1918.

Reidy, M. S.: Tides of History: Ocean Science and Her Majesty's Navy, The University of Chicago Press, London, https://doi.org/10.7208/chicago/9780226709338.001.0001, 2008.

Rose, H. and Rose, S. P. R.: Science and Society, Allen Lane, London, 1969.

Scoffield, J.: Bidston Observatory: The Place and the People, Countyvise Ltd, Birkenhead, 2006.

Shoolbred, J. N.: The tidal regime of the river Mersey, as affected by the recent dredgings at the bar in Liverpool bay, Proc. R. Soc. Lon. Ser.-A, 78, 161-166, https://doi.org/10.1098/rspa.1906.0068, 1906.

Smythe-Wright, D., Gould, W. J., McDougall, T. J., Sparnocchia, S., and Woodworth, P. L.: IAPSO: tales from the ocean frontier, Hist. Geo Space. Sci., 10, 137-150, https://doi.org/10.5194/hgss10-137-2019, 2019.

Varcoe, I.: Organizing for Science in Britain, Oxford University Press, Oxford, 1974.

Warburg, H. D.: The Admiralty Tide Tables and North Sea Tidal Predictions, Geogr. J., 53, 308-326, https://doi.org/10.2307/1779472, 1919.

Warwick, A.: Cambridge Mathematics and Cavendish Physics: Cunningham, Campbell and Einstein's Relativity 1905-1911 Part I: The Uses of Theory, Stud. Hist. Philos. Sci. Part A, 23, 625-656, https://doi.org/10.1016/0039-3681(92)90015-x, 1992.

Warwick, A.: The Laboratory of Theory or What's Exact About the Exact Sciences?, in: The Values of Precision, edited by: Wise, M. N., Princeton University Press, Chichester, 1997.

Warwick, A.: Masters of Theory: Cambridge and the Rise of Mathematical Physics, University of Chicago Press, London, https://doi.org/10.7208/chicago/9780226873763.001.0001, 2003.

Weir, G. E.: An Ocean in Common: American Naval Officers, Scientists, and the Ocean Environment, Texas A\&M University Press, College Station, Texas, 2001.

Woodworth, P. L.: Tide prediction machines at the Liverpool Tidal Institute, Hist. Geo Space. Sci., 11, 15-29, https://doi.org/10.5194/hgss-11-15-2020, 2020. 